\title{
Analisis Metabolomik Pada Interaksi Padi dan Bakteri
}

\section{Metabolomics Analysis on the Interaction of Rice and Bacteria}

\author{
BRIAN THEOWIDAVITYA, MAFRIKHUL MUTTAQIN, MIFTAHUDIN, ARIS \\ TJAHJOLEKSONO*
}

\author{
Departemen Biologi, Fakultas MIPA, Institut Pertanian Bogor, Kampus IPB Dramaga, Bogor 16680
}

Diterima 11 Maret 2019/Disetujui 31 Mei 2019

\begin{abstract}
Mutualistic plant-microbe interaction can increase the availability or absorption of nutrients and affect plant metabolism. Metabolomics is the study of all metabolites contained in living beings at a specific time. This research aims to study the effect of metanotrophic bacteria (BGM 9 isolate) and nitrogen-fixing bacteria (ITJ 7 isolate) on rice plant growth and reveal the information about metabolites produced by rice plant interacting with the bacteria. Three rice plant varieties (Ciherang, Hawara Bunar, and IR64) were grown on liquid media (Yoshida solution) and were inoculated with the bacteria five weeks after planting. Metabolites in the liquid media were detected seven days after inoculation using Liquid Chromatography-Mass Spectrometry and analyzed using MassLynx v4.1. The results showed that the bacterial inoculation had significant effect on rice growth. Chromatograms resulted from LC-MS showed there are 34 unique peaks from Ciherang, 21 unique peaks from Hawara Bunar, and 30 unique peaks from IR64. The unique peaks in each variety were affected by the bacteria inoculation treatments.
\end{abstract}

Key words: bacteria, interaction, metabolomics, rice

\section{PENDAHULUAN}

Interaksi mutualistik antara tumbuhan dan mikroba dapat meningkatkan ketersediaan atau penyerapan unsur hara untuk pertumbuhan tumbuhan. Selain itu, beberapa mikroba diketahui mampu mempengaruhi metabolisme tumbuhan dan mengatur produksi atau degradasi dari fitohormon (Wu et al. 2009). Banyak bakteri hidup bebas secara aktif merespon eksudat akar dengan mengatur program transkripsi mereka terhadap sifat-sifat yang terlibat dalam kemotaksis, kolonisasi akar, dan metabolisme energi. Segera sesudah mendiami epidermis akar, bakteri secara khas membuat biofilm di mana komunitas multiselular ditutupi oleh matriks ekstraselular dari zat polimer terutama exopolysaccharides (EPS). Pembentukkan biofilm menjadi dasar kolonisasi akar oleh bakteri. Peristiwa tersebut dirangsang oleh dinding sel inang yang mengeluarkan polisakarida sebagai molekul sinyal untuk ekspresi gen produksi matriks pada bakteri. Dalam matriks EPS, sel-sel bakteri berintegrasi dengan inang dan melepaskan sinyal untuk produksi dan pelepasan senyawa untuk mendukung pertumbuhan tumbuhan, penyerapan nutrisi, dan Induced Systemic Resistance. Secara konseptual, matriks ini dapat dianggap sebagai

*Penulis korespondensi:

E-mail: aristj2009@gmail.com antarmuka mutualistik tumbuhan inang dan bakteri untuk pertukaran zat terlarut dan informasi kimia yang menguntungkan (Pieterse et al. 2014).

Isolat BGM 9 adalah bakteri metanotrof yang diisolasi dari tanah sawah irigasi di Bogor. Isolat BGM 9 memiliki kemampuan oksidasi metan tertinggi di antara bakteri hasil isolasi lainnya dan memiliki aktivitas sMMO (soluble Metan Monooksigenase) (Hapsary 2008). Isolat BGM 9 juga mampu melakukan fiksasi nitrogen dan mengakumulasi amonium (Hapsary 2008; Astuti 2009). Menurut identifikasi yang dilakukan oleh Astuti (2009), Bakteri BGM 9 memiliki kemiripan sebesar 85\% dengan Methylococcus capsulatus strain Texas yang memiliki ciri-ciri: sel bulat dengan penataan rantai, gram negatif, tidak membentuk spora, dan non-motil. Bakteri metanotrof adalah mikroorganisme aerobik yang mampu tumbuh dan berkembang dengan metan sebagai satu-satunya sumber energi. Oleh karena itu, oksidasi metan dapat terjadi pada lingkungan mikro yang bersifat aerobik pada zona perakaran dan bahkan pada lapisan tanah yang tinggi toksisitas mineralnya. Proses oksidasi metan diinisiasi oleh enzim metan monooksigenase yang mengubah metan menjadi metanol dan mampu mendegradasi senyawasenyawa polutan (Graham et al. 1992). Isolat bakteri ITJ 7 diisolasi dari tanah perkebunan asal Jambi dan teridentifikasi 100\% mirip dengan Beijerinckia 
fluminensis. Isolat ITJ 7 merupakan mikroba tanah penambat nitrogen berdasarkan kemampuannya memiliki laju pertumbuhan yang baik pada media bebas nitrogen serta dapat menghasilkan indole3-acetic acid maksimum pada fase pertumbuhan stasioner (Harca et al. 2014). Isolat bakteri BGM 9 dan ITJ 7 sama-sama memiliki hasil metabolisme yang menguntungkan bagi pertumbuhan tumbuhan sehingga berpotensi dimanfaatkan sebagai pupuk hayati.

Metabolomik adalah analisis komprehensif terhadap semua metabolit yang terkandung dalam makhluk hidup pada suatu waktu yang spesifik. Metabolomik menerangkan proses biokimia dan peran suatu metabolit dalam metabolisme serta dapat dimanfaatkan secara komplemen bersama dengan genomik, transkriptomik, dan proteomik untuk memahami fisiologi suatu organisme secara holistik dan mendalam. Metabolomik bergantung kepada teknologi terkini seperti LC-MS (Liquid Chromatography-Mass Spectrometry) yang mempunyai resolusi tinggi dan dapat mengukur jumlah metabolit yang besar secara baik (Simoh et al. 2014). LC-MS sering digunakan untuk membuat profil metabolit sekunder pada metabolomik tumbuhan (Okazaki dan Saito 2012). Metabolomik memainkan peran penting dalam penelitian tentang tumbuhan yang mengandung berbagai kelas metabolit yang lebih kompleks dibandingkan hewan dan mikroba. Metabolit yang terkandung dalam tumbuhan diperkirakan melebihi 200,000 jenis dengan diversitas yang sangat luas (Simoh et al. 2014). Jika dibandingkan dengan molekul lain yang juga diidentifikasi secara omik atau menyeluruh seperti DNA, RNA, dan protein maka metabolit terdiri atas lebih banyak grup yang heterogen berdasarkan komponen kimia dan fisika serta bervariasi sangat luas dalam ukuran, polaritas, kuantitas, dan stabilitas. Metabolit sekunder tumbuhan tidak secara langsung terlibat dalam pertumbuhan dan perkembangan tumbuhan namun mereka memiliki peran penting dalam fisiologi tumbuhan seperti racun untuk predator, penarik polinator, obat-obatan, dan rasa serta aroma pada produk tanaman (Okazaki dan Saito 2012).

Selain dipengaruhi oleh faktor genetik, proses fisiologi suatu organisme juga dipengaruhi oleh faktor lingkungan biotik maupun abiotik. Salah satu faktor biotik yang dapat berpengaruh adalah bakteri rizosfer. Penelitian ini bertujuan untuk mempelajari pengaruh bakteri metanotrof (isolat BGM 9) dan bakteri penambat nitrogen (isolat ITJ 7) terhadap pertumbuhan tanaman padi serta mengungkapkan informasi tentang metabolit yang dihasilkan oleh tanaman padi yang berinteraksi dengan bakteri.

\section{BAHAN DAN METODE}

Waktu dan Tempat. Penelitian dilaksanakan di Laboratorium Fisiologi dan Biologi Molekular Tumbuhan dan Rumah Kaca Departemen Biologi, FMIPA, Institut Pertanian Bogor pada Agustus hingga November 2016. Analisis metabolomik dilakukan dengan menggunakan jasa Pusat Laboratorium Forensik, Kepolisian Republik Indonesia pada bulan November 2016.

Bahan. Bahan yang digunakan adalah media Yoshida (Yoshida et al. 1976), media Nitrogen Free Bromthymol Blue (NFB) (Okon et al. 1977), media Nitrat Mineral Salts (NMS) + metanol 1\% (Whittenbury et al. 1970), media Nutrient Broth (NB), isolat bakteri BGM 9, isolat bakteri ITJ 7 (Beijerinckia fluminensis), dan biji padi (Oryza sativa) varietas Ciherang, Hawara Bunar, dan IR64.

Alat. Alat yang digunakan antara lain autoklaf, Biological Safety Cabinet (BSC), neraca analitik, oven, wadah plastik, pompa aquarium, wadah gelas kertas, styrofoam yang telah dilubangi, Liquid Chromatography-Mass Spectrometry (LC-MS), perangkat lunak MassLynx v4.1.

\section{Prosedur Percobaan.}

Sterilisasi dan Penanaman Biji. Biji padi terlebih dahulu dimasukkan ke dalam oven $37^{\circ} \mathrm{C}$ selama 24 jam. Setelah itu, sterilisasi permukaan dilakukan dengan etanol $70 \%$ selama 5 menit dilanjutkan dengan $\mathrm{NaOCl} 0.5 \%$ selama 15 menit. Biji padi yang telah disterilisasi dibilas dengan akuades sebanyak tiga kali lalu direndam di dalam akuades steril selama 24 jam. Tahap selanjutnya adalah pengecambahan biji yang dilakukan di dalam cawan petri selama 48 jam dengan kondisi gelap. Biji padi yang sudah berkecambah kemudian ditanam pada jaring-jaring plastik yang mengapung di atas media Yoshida dengan $\mathrm{pH} 5$ dan dipelihara di dalam laboratorium pada suhu ruang selama 2 minggu.

Peremajaan Bakteri. Isolat bakteri diremajakan dengan media cair NMS + metanol $1 \%$ untuk bakteri BGM 9 dan NFB untuk bakteri ITJ 7. Seminggu sebelum inokulasi, bakteri ITJ 7 diremajakan kembali dengan media NB.

Perawatan Padi dan Inokulasi Bakteri. Bibit padi dipindahkan dari jaring-jaring plastik ke dalam wadah gelas kertas. Wadah tersebut sudah dilengkapi dengan styrofoam yang memiliki 3 buah lubang untuk masing-masing bibit kemudian ditempatkan ke dalam rumah kaca. Perawatan dilakukan dengan mengganti media Yoshida setiap seminggu sekali. Pada minggu ke-6 setelah tanam, wadah gelas kertas diganti dan dilakukan inokulasi dengan bakteri BGM 9 dan ITJ 7.

Pengamatan Pertumbuhan Padi dan Analisis Metabolomik. Tinggi tajuk dan jumlah daun diamati 
selama 6 minggu sejak ditanam pada gelas kertas. Pertambahan tinggi tanaman, panjang akar, jumlah anakan, bobot basah, dan bobot kering akar serta tajuk diamati saat pasca pemanenan yaitu ketika minggu ke- 6 berakhir. Pertambahan tinggi tanaman dihitung dengan rumus sebagai berikut:

$$
\mathrm{Pt}=\frac{(\text { Tm ke-6) }-(\text { Tm ke-5) } \times 100 \%}{\text { Tm ke-5 }}
$$

Keterangan:

$$
\begin{array}{ll}
\mathrm{Pt} & \text { : Pertambahan tinggi } \\
\mathrm{Tm} & \text { : Tinggi minggu }
\end{array}
$$

Sampel cairan sebanyak 2-3 ml dari wadah gelas kertas tempat tumbuh padi yang sudah diinokulasi bakteri selama satu minggu diambil menggunakan pipet mikro dan dimasukan ke dalam botol kaca kecil. Sampel kemudian dibawa ke Pusat Laboratorium Forensik untuk dianalisis secara metabolomik menggunakan LC-MS.

Analisis Data. Data pengamatan pertumbuhan padi dianalisis secara statistik menggunakan perangkat lunak SPSS v16. Data analisis LC-MS diolah dengan menggunakan perangkat lunak MassLynx v4.1.

\section{HASIL DAN PEMBAHASAN}

Hasil analisis statistik menunjukan bahwa tinggi tanaman dan jumlah daun sebelum diinokulasi tidak berbeda nyata antara padi varietas Ciherang dan IR64, namun keduanya berbeda nyata dengan padi varietas Hawara Bunar (Tabel 1). Padi varietas Ciherang dan IR64 merupakan padi subspesies Indica sedangkan varietas Hawara Bunar adalah padi subspesies Japonica. Perbedaan morfologi dapat terlihat yaitu varietas padi Hawara Bunar lebih tinggi dan memiliki jumlah daun yang lebih sedikit dibandingkan kedua varietas lainnya. Hal ini sesuai dengan pernyataan Sutaryo et al. (2008) bahwa padi Japonica berpostur tinggi dan mudah rebah. Pada minggu ke-2 pertambahan tinggi setiap varietas berbeda antara satu dengan yang lainnya (Tabel 1). Perbedaan morfologi dan respon adaptif masing-masing varietas mempengaruhi kemampuan mereka dalam berinteraksi dengan organisme lain (Singh et al. 2014).

Inokulasi dengan bakteri dilakukan untuk melihat bagaimana padi merespon keberadaan mikroorganisme di sekitar perakarannya. Respon positif diharapkan menghasilkan simbiosis mutualisme antara bakteri dan padi. Bakteri isolat BGM 9 dan ITJ 7 masing-masing memiliki hasil metabolisme yang menunjang pertumbuhan tanaman padi. Rentang waktu pasca inokulasi sebelum pengambilan data ialah satu minggu. Selama waktu tersebut masing-masing varietas mengalami respon yang berbeda. Hasil analisis statistik menggunakan SPSS mengungkapkan bahwa varietas padi memiliki pengaruh terhadap seluruh karakter yang diukur kecuali jumlah daun dan anakan. Perlakuan inokulasi bakteri memiliki pengaruh pada bobot basah dan kering akar. Tinggi tajuk, panjang akar, bobot basah akar, dan bobot kering akar dipengaruhi oleh interaksi antara varietas padi dengan bakteri. Di antara tiga varietas padi yang diteliti, hanya padi varietas Hawara Bunar yang tingginya dipengaruhi secara nyata oleh perlakuan inokulasi bakteri BGM 9 dan ITJ 7. Persentase pertambahan tinggi padi varietas Hawara Bunar berbeda nyata bila dibandingkan dengan kontrol pada perlakuan bakteri ITJ 7, sedangkan padi varietas Ciherang dan IR64 tidak berbeda nyata pada kedua perlakuan (Tabel 2). Hasil tersebut menunjukkan bahwa interaksi antara padi dan bakteri mempengaruhi metabolisme dari padi varietas Hawara Bunar sehingga meningkatkan tinggi tajuk secara signifikan. Keunikan tersebut dapat dikarenakan perbedaan subspesies antara varietas Ciherang dan IR64 (Indica) dengan varietas Hawara Bunar (Japonica). Padi subspesies Japonica pada umumnya memiliki jumlah senyawa yang mengandung nitrogen seperti asam-asam amino lebih tinggi dibandingkan Indica (Hu et al. 2014). Menurut Syaiful et al. (2013) sebenarnya fiksasi nitrogen oleh bakteri penambat $\mathrm{N}$ tidak cukup memenuhi kebutuhan $\mathrm{N}$ pada tanaman inang karena bakteri juga membutuhkan $\mathrm{N}$ untuk pertumbuhannya. Pertambahan tinggi tanaman kerap diasosiasikan dengan ketersediaan unsur $\mathrm{N}$ sehingga diduga bahwa pertumbuhan positif padi varietas Hawara Bunar disebabkan senyawa yang dihasilkannya mampu merangsang pembelahan bakteri lebih cepat. Hal tersebut membuat laju fiksasi $\mathrm{N}$ bakteri yang terjadi lebih cepat sehingga merangsang pertambahan tinggi padi varietas Hawara Bunar sebagai efek

\begin{tabular}{|c|c|c|c|c|c|c|c|c|c|c|}
\hline \multirow{2}{*}{ Varietas } & \multicolumn{5}{|c|}{ Tinggi tajuk $(\mathrm{cm})$ pada minggu ke- } & \multicolumn{5}{|c|}{ Jumlah daun minggu ke- } \\
\hline & 1 & 2 & 3 & 4 & 5 & 1 & 2 & 3 & 4 & 5 \\
\hline Ciherang & $23.63^{\mathrm{a}}$ & $34.07^{\mathrm{a}}$ & $42.65^{\mathrm{a}}$ & $51.65^{\mathrm{a}}$ & $58.57^{\mathrm{a}}$ & 4 & 6 & 7 & 7 & 8 \\
\hline Hawara Bunar & $28.96^{\mathrm{b}}$ & $42.07^{\mathrm{c}}$ & $49.74^{b}$ & $58.87^{b}$ & $65.37^{\mathrm{b}}$ & 3 & 4 & 5 & 5 & 5 \\
\hline IR64 & $24.00^{\mathrm{a}}$ & $37.72^{b}$ & $45.09^{\mathrm{a}}$ & $53.89^{\mathrm{a}}$ & $60.07^{\mathrm{a}}$ & 4 & 6 & 7 & 8 & 9 \\
\hline
\end{tabular}
domino.

Tabel 1. Tinggi tanaman dan jumlah daun minggu ke-1 sampai minggu ke-5

Angka-angka pada kolom yang sama jika diikuti huruf yang sama maka tidak berbeda nyata pada taraf uji 5\% DMRT 
Panjang akar padi varietas Hawara Bunar tidak berbeda antara tanaman yang diinokulasi dengan yang tidak diinokulasi (kontrol). Sebaliknya pada padi varietas Ciherang dan IR64 perlakuan inokulasi memberi hasil yang nyata tetapi tidak oleh isolat bakteri yang sama. Bobot basah akar padi varietas Hawara Bunar dan IR64 dipengaruhi oleh perlakuan inokulasi. Bobot basah akar padi varietas Hawara Bunar hanya dipengaruhi oleh perlakuan bakteri ITJ 7 sedangkan padi varietas IR64 dipengaruhi oleh masing-masing bakteri. Dalam hal bobot kering akar, hanya padi varietas IR64 yang dipengaruhi oleh perlakuan yaitu inokulasi dengan isolat bakteri BGM 9 (Tabel 3).

Pengaruh nyata yang ditunjukkan oleh semua parameter ukur akar dengan interaksi padi dan bakteri dapat disebabkan karena bakteri pada tumbuhan secara dominan berada di sistem perakaran. Tumbuhan menyalurkan sampai $40 \%$ hasil fotosintesisnya untuk rizosfer sehingga membuat area di sekitar akar menjadi salah satu habitat paling kaya energi di Bumi (Pieterse et al. 2014). Hal ini menjadi isyarat bahwa rizosfer adalah kunci utama dalam meneliti interaksi antara padi dan bakteri yang menguntungkan. Pada penelitian ini, respon masing-masing varietas tanaman padi terhadap inokulasi bakteri BGM 9 dan ITJ 7 sangatlah beragam dan tidak semua menunjukkan hasil yang positif. Kejadian ini dapat disebabkan oleh banyak hal, salah satunya adalah kemampuan sistem imun tanaman menanggapi keberadaan bakteri secara tiba-tiba atau Induced Systemic Resistance (ISR).
Inisiasi dari ISR terjadi ketika mikroba yang menguntungkan mengkolonisasi sistem perakaran dari tumbuhan inang. Pembentukan asosiasi mutualistik yang sukses terjadi apabila tumbuhan inang dan mikroba merespon sinyal-sinyal timbal balik dan memprioritaskan respon mereka pada perkembangan keuntunganyang bersifat mutualistik. Pada penelitian tentang simbiosis mikoriza dan rhizobium, inang mengeluarkan strigolactones dan flavonoid untuk menstimulasi produksi dari faktorfaktor simbiotik bakteri. Hal ini mengaktivasi jalur sinyal simbiosis pada akar tumbuhan yang diperlukan untuk pembentukan hubungan simbiotik (Pieterse et al. 2014). Hasil minimal atau negatif yang terjadi karena perlakuan inokulasi bakteri dibandingkan kontrol dapat disebabkan oleh sistem imun yang terlalu sensitif sehingga mempengaruhi pertukaran sinyal-sinyal timbal balik antara padi dan bakteri menjadi tidak efektif dan simbiosis mutualisme yang terjadi terhambat. Pada penelitian ini, pengamatan terhadap pertumbuhan padi hanya dilakukan pada 7 hari setelah inokulasi bakteri. Pada jangka waktu tersebut pengaruh bakteri terhadap pertumbuhan tanaman masih belum maksimal. Interaksi antara spesies membutuhkan waktu, disamping itu reaksi padi dilihat dari pertumbuhannya akan lebih jelas jika dipelihara sampai waktu panen seperti penelitian Simarmata et al. (2017) yang melakukan introduksi bakteri dari 2 minggu masa setelah tanam dan dinilai hasilnya setelah panen (100 hari masa setelah tanam).

Tabel 2. Parameter pertumbuhan padi 1 minggu setelah inokulasi bakteri

\begin{tabular}{lccccc}
\hline Varietas & Perlakuan (bakteri) & Tinggi $(\mathrm{cm})$ & Pertambahan tinggi (\%) & Jumlah daun & Jumlah anakan \\
\hline Ciherang & BGM 9 & $64.78^{\mathrm{a}}$ & $13.42^{\mathrm{ab}}$ & 6 & 2 \\
& ITJ 7 & $65.78^{\mathrm{a}}$ & $9.33^{\mathrm{a}}$ & 7 & 2 \\
\multirow{4}{*}{ Hawara bunar } & Kontrol & $67.44^{\mathrm{a}}$ & $15.81^{\mathrm{ab}}$ & 6 & 2 \\
& BGM 9 & $74.00^{\mathrm{b}}$ & $10.27^{\mathrm{ab}}$ & 6 & 2 \\
\multirow{5}{*}{ IR64 } & ITJ 7 & $79.22^{\mathrm{b}}$ & $18.91^{\mathrm{b}}$ & 5 & 2 \\
& Kontrol & $67.44^{\mathrm{a}}$ & $8.05^{\mathrm{a}}$ & 5 & 3 \\
& BGM 9 & $67.67^{\mathrm{a}}$ & $10.58^{\mathrm{ab}}$ & 8 & 2 \\
& ITJ 7 & $64.67^{\mathrm{a}}$ & $9.10^{\mathrm{a}}$ & 8 & 3 \\
\hline
\end{tabular}

Angka-angka pada kolom yang sama jika diikuti huruf yang sama maka tidak berbeda nyata pada taraf uji 5\% DMRT

Tabel 3. Panjang akar, bobot basah, dan bobot kering padi 1 minggu setelah inokulasi bakteri

\begin{tabular}{|c|c|c|c|c|c|c|}
\hline \multirow[t]{2}{*}{ Varietas } & \multirow[t]{2}{*}{ Perlakuan (bakteri) } & \multirow[t]{2}{*}{ Panjang akar (cm) } & \multicolumn{2}{|c|}{ Bobot kasah (gr) } & \multicolumn{2}{|c|}{ Bobot kering (gr) } \\
\hline & & & Tajuk & Akar & Tajuk & Akar \\
\hline \multirow[t]{3}{*}{ Ciherang } & BGM 9 & $10.94^{\mathrm{a}}$ & 4.66 & $3.38^{\mathrm{bc}}$ & 0.81 & $0.25^{\mathrm{abc}}$ \\
\hline & ITJ 7 & $15.67^{\mathrm{b}}$ & 5.55 & $3.79^{\mathrm{bc}}$ & 1.03 & $0.36^{\mathrm{de}}$ \\
\hline & Kontrol & $11.89^{\mathrm{a}}$ & 5.94 & $4.17^{\mathrm{cd}}$ & 1.05 & $0.33^{\text {cde }}$ \\
\hline \multirow[t]{3}{*}{ Hawara bunar } & BGM 9 & $17.72^{\mathrm{bc}}$ & 4.46 & $3.05^{\mathrm{ab}}$ & 0.64 & $0.22^{\mathrm{a}}$ \\
\hline & ITJ 7 & $17.17^{\mathrm{bc}}$ & 4.66 & $3.69^{\mathrm{bc}}$ & 0.71 & $0.31^{\text {bcde }}$ \\
\hline & Kontrol & $18.33^{\mathrm{bc}}$ & 3.40 & $2.28^{\mathrm{a}}$ & 0.68 & $0.23^{\mathrm{ab}}$ \\
\hline \multirow[t]{3}{*}{ IR64 } & BGM 9 & $23.39^{\mathrm{d}}$ & 5.69 & $5.30^{\mathrm{e}}$ & 1.09 & $0.38^{\mathrm{e}}$ \\
\hline & ITJ 7 & $19.56^{\mathrm{c}}$ & 5.47 & $4.95^{\mathrm{de}}$ & 1.05 & $0.36^{\mathrm{de}}$ \\
\hline & Kontrol & $18.89^{\mathrm{bc}}$ & 4.26 & $3.25^{\mathrm{abc}}$ & 0.95 & $0.28^{\mathrm{abcd}}$ \\
\hline
\end{tabular}

Angka-angka pada kolom yang sama jika diikuti huruf yang sama maka tidak berbeda nyata pada taraf uji 5\% DMRT 
Pemisahan dengan kromatografi diperlukan untuk menyederhanakan metabolit-metabolit hasil interaksi tumbuhan dan bakteri sehingga komponen yang sudah terpisah selanjutnya dapat dianalisis kelimpahan dan berat molekulnya oleh spektrometri massa (Kusano et al. 2015). Hasil analisis berupa peak atau puncak kromatogram dalam waktu retensi tertentu memperlihatkan waktu suatu senyawa berhasil terpisah dari sampel dan menjadi teridentifikasi. Gambar 1 memperlihatkan kromatogram dari sampel padi varietas Ciherang. Perlakuan inokulasi bakteri menghasilkan peak yang relatif memiliki kemiripan dengan tanaman kontrol (tanpa inokulasi bakteri). Hal ini menjadi indikator bahwa senyawa-senyawa metabolit yang dihasilkan relatif mirip atau memiliki kuantitas yang sangat kecil sekali sehingga sulit terdeteksi secara baik. Metabolomik berbeda dengan analisis genomik, transkriptomik, dan proteomik. Produk yang dihasilkan oleh reaksi metabolisme sangat tinggi variasinya dalam struktur dan komponen kimiawi. Hal ini membuat penentuan keseluruhan rangkaian metabolit pada keadaan fisiologis tertentu menjadi sangat sulit dilakukan bahkan untuk alat sensitif seperti LC-MS. Sifat dinamis dari metabolit yang selalu berubah-ubah konsentrasi dan komposisinya secara cepat untuk merespon stimulus lingkungan juga menambah kompleksitas dalam analisis metabolomik (Tang 2011).

Pada analisis peak kromatogram, peak yang berasal dari media tetap ditemukan tetapi presentasinya masih kecil jika dibandingkan dengan peak yang berasal dari perlakuan. Hal ini diduga akibat adanya senyawa kimia media tumbuh seperti unsur hara atau cairan pelarut yang digunakan untuk melarutkan sampel LC-MS.
Peak dari media dieleminasi dan hanya peak yang berasal dari sampel saja yang dianalisis lebih lanjut. Peak pada setiap varietas dibedakan menjadi peak tidak unik yang memiliki persamaan minimal dengan satu sampel lainnya dari varietas yang berbeda dan peak unik yang khusus dimiliki oleh satu jenis sampel saja dan tidak ditemukan pada jenis sampel lainnya. Jumlah peak unik pada padi varietas Ciherang, Hawara Bunar, dan IR64 masing-masing adalah 21, 34, dan 30 (Gambar 2). Peak yang serupa mengindikasikan adanya kemiripan dalammerespon perlakuan sedangkan peak yang unik diakibatkan oleh respon yang lebih spesifik dan beranekaragam pada masing-masing individu dalam varietas yang berbeda.

Peak unik dianalisis dan dibedakan berdasarkan perlakuan, sehingga dapat diketahui dari perlakuan manakah peak tersebut berasal (Tabel 4). Padi varietas Ciherang menunjukkan jumlah peak unik yang lebih banyak pada perlakuan bakteri BGM 9 dan ITJ 7 dibandingkan kontrol. Padi varietas Hawara Bunar juga menunjukkan jumlah peak yang lebih banyak namun hanya pada perlakuan isolat bakteri BGM 9, sedangkan padi varietas IR64 tidak menunjukkan perbedaan berarti antara kontrol dan kedua perlakuan. Selain peak yang dihasilkan oleh satu perlakuan inokulasi terdapat peak yang didapatkan dari satu varietas namun muncul pada perlakuan inokulasi yang berbeda. Peak pada B-K (Peak unik yang muncul pada isolat bakteri BGM 9 dan Kontrol) memiliki jumlah terbanyak di semua varietas terutama pada padi varietas IR64. Maka dari itu, walaupun padi varietas IR64 tidak terlalu menunjukkan perbedaan nyata pada tiap perlakuan namun kombinasi perlakuan B-K menunjukkan hasil yang cukup besar (Tabel 4). Dilihat dari jumlah total padi varietas Ciherang dan

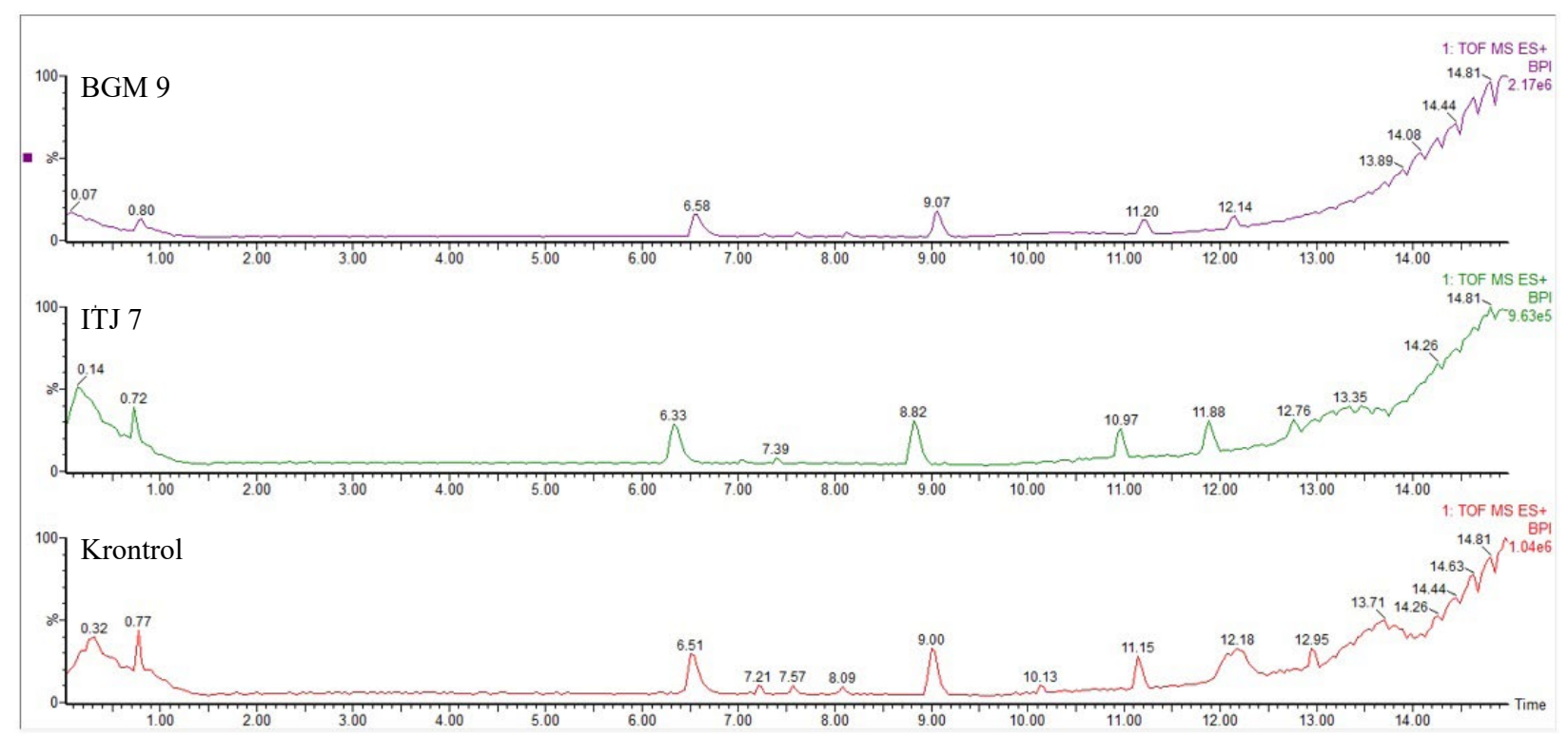

Gambar 1. Kromatogram sampel media tanam padi varietas Ciherang yang diinokulasi dengan bakteri metanotrof (BGM 9), diinokulasi dengan bakteri penambat nitrogen (ITJ 7), dan tidak diinokulasi (Kontrol) 


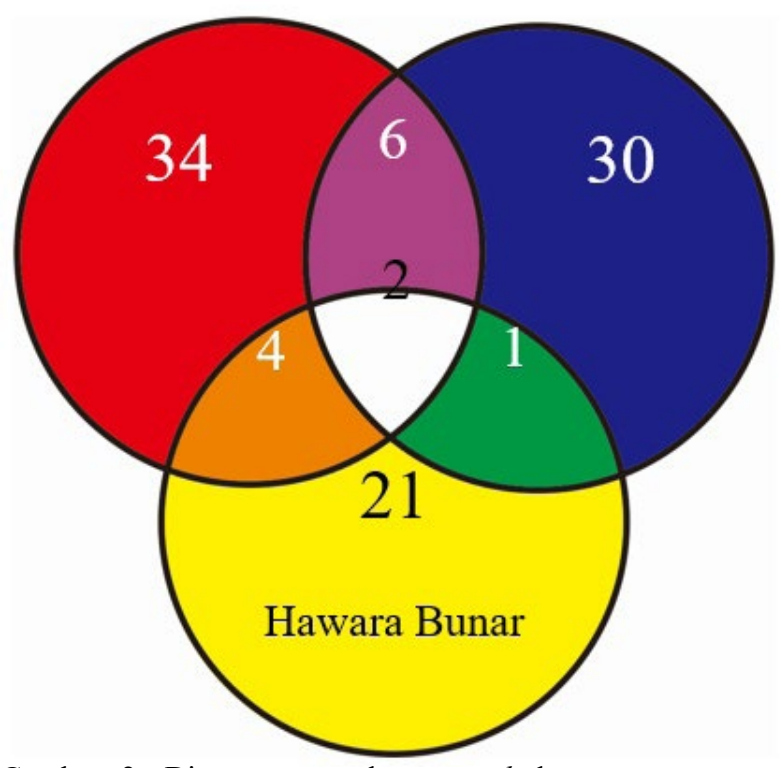

Gambar 2. Diagram penyebaran peak kromatogram antar varietas padi

Tabel 4. Jumlah peak unik pada padi varietas Ciherang, Hawara Bunar, dan IR 64

Varietas BGM 9 ITJ 7 Kontrol B-I(*) B-K(*) I-K(*) Total

\begin{tabular}{lccccccc} 
& $(\mathrm{B})$ & $(\mathrm{I})$ & $(\mathrm{K})$ & & & & \\
\hline Ciherang & 10 & 12 & 5 & 3 & 3 & 1 & 34 \\
Hawara & 13 & 3 & 2 & - & 3 & - & 21
\end{tabular}

$\begin{array}{llllllll}\text { bunar } & & & & & \\ \text { IR64 } & 6 & 8 & 7 & 1 & 7 & 1 & 30\end{array}$

*: B-I (Peak unik yang muncul pada kedua isolat bakteri), B-K (Peak unik yang muncul pada isolat bakteri BGM 9 dan Kontrol), I-K (Peak unik yang muncul pada isolat bakteri ITJ 7 dan Kontrol)

IR64 menunjukkan jumlah peak yang hampir setara, berbeda dengan padi varietas Hawara Bunar yang menghasilkan lebih sedikit peak (Tabel 4). Perbedaan tersebut dapat disebabkan oleh perbedaan subspesies antara varietas dimana Ciherang dan IR64 merupakan padi subspesies Indica dan Hawara Bunar adalah padi subspesies Japonica, sehingga karena keunikan metabolit dan adaptasi mengakibatkan perbedaan dalam berinteraksi dengan bakteri inokulasi.

Padi subspesies Japonica dan Indica telah diketahui memiliki hasil metabolit yang sangat berbeda variasi dan kelimpahannya (Hu et al. 2014; Kusano et al. 2015). Walaupun padi Japonica dan Indica telah dilaporkan memiliki asal bersama namun mereka telah didomestikasikan dalam kondisi lingkungan yang sangat berbeda. Padi Japonica secara umum ditanam di iklim temperate dengan suhu dingin sedangkan padi Indica umumnya ditumbuhkan di iklim tropis dan sub tropis. Perbedaan metabolit antara padi subspesies Japonica dan Indica diasosiasikan dengan 3 fungsi metabolisme utama yaitu metabolisme nitrogen, respon terhadap stres, dan penyimpanan serta translokasi nutrisi anorganik. Perbedaan metabolismemasing-masing varietas menjadi penting karena hal tersebut banyak mempengaruhi respon mereka terhadap bakteri dan sebaliknya. Senyawa yang mengandung nitrogen lebih banyak ditemukan pada subspesies Japonica dan membuat perbedaan dari efisiensi pengambilan nitrogen pada pertumbuhan vegetatif kedua subspesies. Selain itu, metabolit yang berhubungan terhadap penyimpanan nutrisi anorganik seperti fitat, glukonat, nikotinamid diketahui lebih tinggi di dalam padi subspesies Japonica (Hu et al. 2014). Akumulasi $\mathrm{Cu}, \mathrm{Fe}, \mathrm{Zn}$, dan $\mathrm{Mn}$ di sistem perakaran padi subspesies Japonica juga lebih tinggi dibandingkan padi subspesies Indica (Yoshihara et al. 2010). Padi subspesies Japonica mengakumulasi metabolit yang berasosiasi dengan respon stres seperti alanin, linolenat, dan glukonat lebih tinggi namun memiliki metabolit antioksidan lebih rendah sehingga padi subspesies Indica lebih kuat menghadapi oksidasi sedangkan subspesies Japonica lebih kuat menghadapi stres (Hu et al. 2014).

Tumbuhan adalah organisme yang menghasilkan metabolit sekunder paling kompleks dibandingkan dengan hewan dan bakteri serta memiliki kekayaan genom yang paling besar karena adaptasi yang spesifik terhadap tempat tumbuh. Data peak membuktikan bahwa interaksi antara padi dan bakteri merupakan suatu aktivitas kimiawi dan biologis yang sangat kompleks dan unik. Pada penelitian Kusano et al. (2015) tentang eksplorasi kekayaan senyawa kimia pada 70 kultivar padi ditemukan 1,652 jenis peak. Namun hanya 156 yang teridentifikasi sedangkan sisanya masih belum diketahui karena tidak ditemukan pada bank senyawa kimia. Metabolit yang teridentifikasi meliputi metabolit primer (gula, asam amino, asam organik, asam lemak, basa nukleat) dan metabolit sekunder yang amat beragam seperti fitohormon dan senyawa volatile. Senyawa aromatik yang telah teridentifikasi pada padi mencapai lebih dari 300 senyawa dan 2-acetyl-1-pyrroline adalah mayoritas yang terdeteksi (Buttery et al. 1982). Metabolit lain yang ditemukan adalah CPGECs (cofactors, prosthetic groups, and electron carriers) (Hu et al. 2014). Metabolit-metabolit tersebut dikeluarkan secara spesifik oleh tanaman untuk mengendalikan jenis, kepadatan, dan ekspresi gen bakteri untuk menunjang proses pertumbuhan dan perkembangan mereka (Chapparo et al. 2014).

\section{KESIMPULAN}

Inokulasi bakteri berpengaruh nyata terhadap pertumbuhan padi tetapi dengan pola yang berbeda. Kromatogram antar varietas padi yang diinokulasi dengan bakteri memiliki kemiripan namun hasil analisis menunjukkan adanya 34 peak unik dari Ciherang, 21 peak unik dari Hawara Bunar, dan 30 peak unik dari IR64. Peak unik pada masing-masing varietas dipengaruhi oleh perlakuan inokulasi. 


\section{UCAPAN TERIMA KASIH}

Penelitian ini menggunakan dana Penelitian Unggulan Perguruan Tinggi (PUPT) sesuai mandat Divisi Kementerian Riset Teknologi dan Pendidikan Tinggi Republik Indonesia.

\section{DAFTAR PUSTAKA}

Astuti DD. 2009. Karakterisasi fisiologi dan identifikasi molekuler isolat-isolat bakteri metanotrof asal sawah wilayah Bogor dan Sukabumi [Skripsi]. Bogor: Institut Pertanian Bogor.

Buttery RG, Ling LC, Juliano BO. 1982. 2-Acetyl-1-pyrroline-an important aroma component of cooked rice. Chem Ind 23:958-959.

Chapparo JM, Badri DV, Vivanco JM. 2014. Rhizosphere microbiome assemblage is affected by plant development. ISME J 8:790-803.

Graham DW, Korich DG, Leblanc RP, Sinclair NA, Arnold RG. 1992. Applications of a colorimetric plate assay for soluble methane monooxygenase activity. Appl Environ Microbiol 58:2231-2236.

Harca NN, Mubarik NR, Wahyudi AT. 2014. Isolation and identification of nitrogen fixing bacteria and idole acetic acid producing bacteria from oil palm plantation in Jambi Indonesia. Int Environ Appl 9:546-553.

Hapsary W. 2008. Isolasi dan karakterisasi bakteri metanotrof asal sawah di Bogor dan Sukabumi [Skripsi]. Bogor: Institut Pertanian Bogor.

Hu C, Shi J, Quan S, Cui B, Kleesen S, Nikoloksi Z, Tohge T, Alexander D, Guo L, Lin H, Wang J, Cui X, Rao J, Luo Q, Zhao X, Fernie AR, Zhang D. 2014. Metabolic variation between japonica and indica rice cultivars as revealed by non-targeted metabolomics. Nature 4:5067.

Kusano M, Yang Z, Okazaki Y, Nakabayashi R, Fukushima A, Saito K. 2015. Using metabolomic approaches to explore chemical diversity in rice. Mol Plant 8:58-67.

Okazaki Y, Saito K. 2012. Recent advances of metabolomics in plant biotechnology. Plant Biotechnol Rep 6:1-15.
Okon Y, Albrecht SL, Burris RH. 1977. Methods for growing spirillum lipoferum and for counting it in pure culture and in association with plants. Appl Environ Microbiol 33:85-88.

Pieterse CMJ, Zamioudis C, Berendsen RL, Weller DM, Van Wees SCM, Bakker PAHM. 2014. Induced sytemic resistance by beneficial microbes. Annu Rev Phytopathol $52: 347-375$

Simoh S, Zainal A, Rahman ZA. 2014. Teknologi metabolomik dalam pertanian. Bul Tekno MARDI 5:85-93.

Singh A, Braun J, Decker E, Hans S, Wagner A, Weisser WW, Zytynska SE. 2014. Plant genetic variation mediates an indirect ecological effect between belowground earthworms and aboveground aphids. BMC Ecol 14:25.

Sutaryo B, Samaullah MY, Satoto. 2008. Ragam genetik dan daya waris karater agronomis beberapa padi hibrida Japonica. In: Prosiding Simposium V Tanaman Pangan. Penelitian dan Pengembangan Padi II. Pusat Penelitian dan Pengembangan Tanaman Pangan Litbang Pertanian.

Simarmata T, Hersanti, Turmuktini T, Fitriatin BN, Setiawati MR, Purwanto. 2017. Application of bioameliorant and biofertilizers to increase the soil health and rice productivity. HAYATI J Biosci 23:181-184.

Syaiful SA, Syam'un E, Dachlan A, Jusoff K, Haerani N. 2013. The effect of inoculating nitrogen-fixing bacteria on production of rice. World Appl Sci J 26:94-99.

Tang J. 2011. Microbial metabolomics. Curr Genom 12:391-403.

Whittenbury R, Phillips KC, Wilkinson JF. 1970. Enrichment, isolation and some properties of methane-utilizing bacteria. J Gen Microbiol 61:205-218.

Wu CH, Bernard SM, Andersen GL, Chen W. 2009. Developing microbe-plant interactions for applications in plantgrowth promotion and disease control, production of useful compounds, remediation, and carbon sequestration. Microb Biotech 2:428-440.

Yoshihara T, Goto F, Shoji K, Kohno Y. 2010. Cross relationships of $\mathrm{Cu}, \mathrm{Fe}, \mathrm{Zn}, \mathrm{Mn}$, and $\mathrm{Cd}$ accumulations in common japonica and indica rice cultivars in Japan. Environ Exp Bot 68:180-187.

Yoshida S, Forno DA, Cock JH, Gomez KA. 1976. Laboratory Manual for Physiological Studies of Rice. Manila (PH): The International Rice Research Institute. p 1-9. 